\title{
An Empirical Evidence of Fisher Effect in Bangladesh: A Time- Series Approach
}

\author{
Md. Gazi Salah Uddin \\ Lecturer \\ School of Business \\ Presidency University \\ Dhaka, Bangladesh \\ Email: salahuddin@presidency.edu.bd
}

\section{Md. Mahmudul Alam}

Deputy Manager

Customer Relationship Management

Brands, Commercial Division

Grameenphone Ltd.

Dhaka, Bangladesh

Email: rony000@gmail.com

Kazi Ashraful Alam

Assistant Professor

Faculty of Business

ASA University Bangladesh

Dhaka, Bangladesh

Email: ashrafka35@gmail.com

\section{Citation Reference:}

Uddin, M.G.S, Alam, M.M., and Alam, K.A. 2008. An Empirical Evidence of Fisher Effect in Bangladesh: A Time-Series Approach, ASA University Review, 2(1), 1-8. (ISSN 1997-6925; Publisher- ASA University, Bangladesh)

This is a pre-publication copy.

The published article is copyrighted by the publisher of the journal. 


\title{
An Empirical Evidence of Fisher Effect in Bangladesh: A Time- Series Approach
}

\author{
Md. Gazi Salah Uddin ${ }^{1}$, Md. Mahmudul Alam ${ }^{2}$, Kazi Ashraful Alam ${ }^{3}$
}

\begin{abstract}
This paper is an attempt to trace the relationship between interest rates and rates of inflation in the economy of Bangladesh. In view of this, a time series approach is considered to examine the empirical evidence of Fisher's effect in the country. By applying OLS and Unit Root test, the estimated value is used to determine the casual relationship between interest rates and inflation for the monthly sample period of August 1996 to December 2003. The empirical results suggest that there does not exist any comovement of inflation with interest rates and the relationship between the variables is also not significant for Bangladesh. Further, the trends advocate that the inflation premium, equal to expected inflation that investors add to real-risk free rate of return, is ineffective in the country.
\end{abstract}

Key Word: Interest rate, Inflation, Bangladesh

\section{Introduction}

The Fisher effect (Fisher, 1930) assumed that the nominal interest rate is the sum of the real rate and expected decline in the purchasing power of money. In other words, the nominal interest rate will be the sum of real interest rate and inflation rate. That means the increase in inflation by 1 percent will be accompanied by 1 percent increase in interest rates. Fisher's hypothesis postulates that changes in expected inflation leave the real interest rate unaltered by creating equal changes in the nominal interest rate. In other words, Fisher effect is also considered as the one for one adjustment of the nominal interest rate to the expected inflation rate.

Since interest rates and inflation are two major central issues in the study of financial markets the Fisher effect has important policy implications for the behavior of interest rates and the efficiency of financial markets. One of the main implications of the interest rate in financial markets is represented by the portfolio effect. The portfolio effect occurs because money and other financial assets are substitutable forms of wealth holding. Interest rates also have an influence on the duration of business cycles. Cagan (1969) has found that although most interest rates have, as a rule, lagged business cycle turns, the interest rate effects on business are not simply added to other factors but interact with them. While the rate of interest is a major item in capital costs, it affects the investment decisions and expenditures behavior. Short-term rates are supposed to influence inventory investment and trade credit, while long-term rates influence capital investment such as plans for plant and equipment installations and for residential housing.

1. Md. Gazi Salah Uddin is a Lecturer, School of Business at Presidency University, Dhaka, Bangladesh

2. Md. Mahmudul Alam is a Deputy Manager, Customer Relationship Management (CRM), Marketing Division, Grameenphone Ltd., Dhaka, Bangladesh.

3. Kazi Ashraful Alam is an Assistant Professor, School of Business at Presidency University, Dhaka, Bangladesh. 
According to the principle of monetary neutrality, an increase in the rate of money growth raises the rate of inflation but does not affect any real variable. An important application of this principle concerns the effect of money on interest rates. These interlinked macroeconomic variables have some economic implications because they link the economy of the present and the economy of the future through their effects on saving and investment. One of the policies that governments adopt in calculating inflation is the use of interest rates mechanism. One implication of high inflation is the loss in welfare caused by falling demand for real balances. In addition, the price mechanism becomes less efficient in an inflationary environment. As a result, the greater uncertainty may reduce both consumption and investment which impairs economic performance.

Analysis shows that the inflation rate in Bangladesh is not highly correlated with the interest rate and the trend of inflation is increasing. According to a release by the Bangladesh Bureau of Statistics in the second week of September 2007, food prices propelled the overall inflation to a 36-year high of 10.10 percent on a point-to-point basis. However, it has been identified that there exists a significant negative relationship between deposit rate of interest and inflation (Mortaza, 2006). This paper is an attempt to find empirical evidence for the Fisher effect in this regard in Bangladesh.

\section{Literature Review}

The Fisher effect theory of a stable one-for-one relationship between nominal interest rates and inflation has proven extremely difficult to maintain empirically. Estimated coefficients in regressions of nominal interest rates on various measures of expected inflation are substantially less than the hypothesized value of one, or alternatively, real interest rates are negatively associated with expected inflation (e.g.,Fama and Gibbon, 1982; Huizinga and Mishkin, 1986, Kandel et al., 1996). It should also be noted that while the Fisher relation suggests a one-to-one response of nominal interest rates to changes in expected inflation, Darby (1975) demonstrates that the effect of nominal rates should be much greater than one since interest income is subject to taxation.

There are several reasons for the inability to detect a full Fisher effect. The first is due to Tobin $(1965,1969)$ who suggests that investors re-balance their portfolios in support of real assets when expected inflation is extremely high. A second explanation asserts that financial markets and investors suffer from money illusion (Modigliani and Cohn, 1979; Tanzi, 1980; Summers, 1983). A third argument made by Evans and Lewis (1995) says that peso problems exist in the market for nominal debt and these problems lead to incorrectly conclude that agents behave irrationally. The fourth explanation comes from Fried and Howitt (1983), who show that financial assets feature a liquidity premium that increases with expected inflation. In other words, the response of nominal interest rates to changes in inflation depends on the riskiness of the bonds. A fifth argument stems from Duck (1993) who asserts that the adjustment of nominal rates can be expected to occur only in the long run. Finally, recent empirical studies (e.g., Mishkin, 1992; Wallace and Warner, 1993; Evans et al., 1994;Engsted, 1995; Crowder, 1997) show that both nominal interest rates and inflation are non stationary processes and thus require appropriate estimation techniques.

Using an expectations model of the term structure of interest rates, Myles Wallace and John Warner (1993) establish the conditions under which innovations in short-term inflation will be transmitted to long-term as well as short-term interest rates. They find that 
if inflation has a unit root in its time series process, then expectations of inflation in future periods will be dominated by the current period rate which in turn will be co-integrated with long-term interest rates as well as short. Martin Evans and Karen Lewis (1995) characterize the shifts in inflation by a Markov switching model. They argue that rational anticipations of infrequent shifts in the inflation process induce significant small sample biases in estimates of the long-run Fisher relationship. These small sample biases may create the appearance of permanent shocks to the real rates even when none are truly present. They examine the long-run relationship between nominal interest rates and inflation and are unable to reject the hypothesis that in the long-run nominal interest rates reflect expected inflation one-for-one. William Crowder and Dennis Hoffman (1996) identify the mechanism responsible for the non-stationarity behavior of the system. Using a bivariate vector error correction model (VECM) they reveal a dynamic behavior of nominal interest rates and inflation. The VECM suggests a specific "causal" ordering where inflation has predictive content for the future course of the interest rates.

Among country specific studies, Liu and Adedeji (2000), Ubide (1997), Leheyda (2005), and Khan and Schimmelpfennig (2006) have recorded clear ideas about the determinants of inflation in developing countries. Most the studies stress money supply as the major source of inflation in the respective economies. In an early study, Taslim (1982) attempted to analyze the inflationary process in Bangladesh in light of the structuralize-monetarist controversy using the data for FY60 to FY80. The author systematically tested both the views in the context of Bangladesh as well as a hybrid model considering both views together. The findings indicate that the rate of change of money supply and devaluation are the most significant explanatory variables. Using co-integration techniques, error correction models and the estimated quarterly data, Akhtaruzzaman (2005) attempted to identify the variables that are believed to generate inflation in Bangladesh during the period 1973-2002. The paper observes that inflation is negatively related with real income. In addition, both the level and rate of the devaluation of exchange rate, growth of money supply and deposit interest rate have statistically significant role in explaining the inflationary process in Bangladesh. Mortaza (2006) presents evidence which suggests that the contribution of increase in money supply to inflation is more significant than other variables such as nominal deposit rate of interest and nominal exchange rate.

\section{Data and Methodology}

This time series study use monthly data for the 89 months from August, 1996 to December, 2003. Data is taken from IFS data series where 'Changes in Consumer Prices' data is used for inflation and 'Sched. Banks Fixed: 3-6 Mos' data is used for interest rate for Bangladesh. For statistical analysis the output is generated by using PC Gives-10+ updated software.

Fisher and Seater (1993) show that the Fisher relation or the (classical) long-run neutrality proposition (implying that a permanent change in the rate of inflation has no longer effect on the level of the real interest rate) can only be tested if the inflation and interest rate series are integrated of order one and do not co-integrate. This is because if the inflation and interest rate series are non-stationary and co-integrate, then a finite vector autoregressive process in first differences does not exist and this is sufficient for rejecting the Fisher effect. The Fisher theory asserts that an increase in monetary growth will raise nominal interest rates, once the monetary expansion leads to price increases and anticipations of inflation. The difference between nominal and real rates of interest was 
first stressed by Irving Fisher (1930) as part of his theory of fluctuations in investment. The Fisher equation can be written as

$$
\left(1+\mathrm{it}_{\mathrm{t}}\right)=\left[1+\mathrm{E}_{\mathrm{t}-1}\left(\mathrm{i}^{*}\right)\right]\left[1+\mathrm{E}_{\mathrm{t}-1}\left(\pi_{\mathrm{t}}\right)\right]
$$

Where, $\mathrm{i}_{\mathrm{t}}=$ the nominal interest rate for a one period bond, maturing at time $\mathrm{t} ; \mathrm{Et}-1\left(\mathrm{it}^{*}\right)=$ the one period real rate of interest expected by the bond market at time $\mathrm{t}-1$ for the bond maturing at time $\mathrm{t} ; \mathrm{E}_{\mathrm{t}-1}\left(\pi_{\mathrm{t}}\right)=$ the inflation rate from $\mathrm{t}-1$ to $\mathrm{t}$, expected by the bond market at time $\mathrm{t}-1$. For low rates of inflation the product $\mathrm{E}_{\mathrm{t}-1}\left(\mathrm{it}_{\mathrm{t}} *\right) * \mathrm{E}_{\mathrm{t}-1}\left(\pi_{\mathrm{t}}\right)$ is insignificant and can be omitted. Therefore, equation (1) becomes simply:

$$
\mathrm{it}_{\mathrm{t}}=\mathrm{E}_{\mathrm{t}-1}\left(\mathrm{i}_{\mathrm{t}}^{*}\right)+\mathrm{E}_{\mathrm{t}-1}\left(\pi_{\mathrm{t}}\right)
$$

Where, both $E_{t-1}\left(i_{t^{*}}\right)$ and $E_{t-1}\left(\pi_{t}\right)$ are unobservable and hence have to be proxy. If expectations are rational as in Fama (1975), the realized future inflation rate can be written as:

$$
\pi_{\mathrm{t}}=\mathrm{E}_{\mathrm{t}-1}\left(\pi_{\mathrm{t}}\right)+\varepsilon \mathrm{t}
$$

Where $\varepsilon_{t}$ is the forecast error of inflation, a zero mean disturbance, and is independent of all information known at time $\mathrm{t}-1$. Since the Fisher equation is interpreted as a long-run equilibrium relation between integrated variables, the real rate has to be stationary. The Fisher equation in (2) says that real rate is the difference between the nominal rate and expected inflation. For the real rate to be affected only by transitory disturbances, any permanent shocks to expected inflation must be reflected in the nominal interest rate. That implies a one-for-one movement of inflation and interest rate in the long run. Let $\pi_{\mathrm{t}}$ be a pure random walk:

$$
\pi_{\mathrm{t}}=\pi_{\mathrm{t}-1}+\mu_{\mathrm{t}}
$$

Then, $\mathrm{E}_{\mathrm{t}-1}\left(\pi_{\mathrm{t}+\mathrm{j}}\right)=\mathrm{E}_{\mathrm{t}-1}\left(\pi_{\mathrm{t}}\right)=\pi \mathrm{t}-1$ for all future $\mathrm{j}$ periods. Thus, if inflation is $\mathrm{I}(1)$, so will be the inflation expected over all future periods. Inflation expectations will be incorporated into interest rates on securities with different maturities. Thus, the I(1) property will be transmitted to interest rates. The link between interest rates and inflation depends on how inflationary expectations are formed. If the one period inflation rate has a single unit root, that is $\mathrm{I}(1)$, the innovations in it will ultimately dominate changes in expectations of future long term inflation. The Fisher hypothesis says that real interest rates do not change much. Therefore, the expected real rate can be expressed as a sum between a constant and a stationary disturbance:

$$
\mathrm{E}_{\mathrm{t}-1}\left(\mathrm{i}_{\mathrm{t}^{*}}\right)=\text { const. }+\lambda_{\mathrm{t}}
$$

Using this assumption, in (2), it is found:

$$
\mathrm{E}_{\mathrm{t}-1}\left(\pi_{\mathrm{t}}\right)=\text { const. }+\mathrm{it}_{\mathrm{t}}-\lambda_{\mathrm{t}}
$$

Equation (6) depicts the theoretical relationship between inflation and interest rate. In empirical studies, if expected inflation is used as a dependent variable, the following equation is estimated: 


$$
\mathrm{E}_{\mathrm{t}-1}\left(\pi_{\mathrm{t}}\right)=\alpha+\beta \mathrm{i}_{\mathrm{t}}+\mathrm{ut}
$$

Thus, testing for the Fisher effect means testing $\beta=1$ in equation (7). Following Mishkin (1992), a test of correlation of interest rates with expected inflation is also a test for the correlation of interest rates and future inflation. When the expression for $\mathrm{E} t-1\left(\pi_{\mathrm{t}}\right)$ given in (3) is replaced in (7), it is found:

$$
\pi_{\mathrm{t}}=\alpha+\beta \mathrm{i}_{\mathrm{t}}+\eta_{\mathrm{t}}
$$

Where $\eta_{t}=\varepsilon_{t}+u_{t}$. The OLS estimate of $\beta$ in equation (8) is a consistent estimate of $\beta$ in equation (7). The error $\eta_{t}$ is orthogonal to $i t$, assuring consistency of the $\beta$ estimate. In empirical studies equation (8) is the one which is used in testing for the Fisher effect.

\section{Result Analysis:}

Unit Root test: The ADF test is used in order to test for stationarity in used variables thereby ensuring non-spurious regressions in the empirical results. An estimate of the test statistics for the time series is compared with the critical value of the ADF test.

\begin{tabular}{ccc}
\hline \multicolumn{4}{c}{ Table No. 1: Unit Root Test (t-ADF value) } \\
\hline Lag & Interest Rate & Inflation \\
\hline 1 & -1.71 & -1.68 \\
2 & -1.73 & -1.43 \\
3 & -1.59 & -1.44 \\
4 & -1.17 & -1.23 \\
5 & -0.63 & -1.30 \\
6 & -0.94 & -1.60 \\
7 & -1.00 & -1.95 \\
8 & -0.97 & -1.86 \\
9 & -0.99 & -1.95 \\
10 & -0.95 & -2.11 \\
\hline
\end{tabular}

The hypothesis- $\mathrm{H}_{0}$ to be non-stationary for both interest rate and inflation series can not be rejected since the test statistics in absolute terms is lower than the critical value both for $95 \%$ and $99 \%$ confidence level. So, both the series are non-stationary or integrated of order 1; I (1).

\section{Regression Test:}

When inflation is regressed on interest rate, the coefficient of determination $\left(\mathrm{R}^{2}\right)$ indicates that only $1.98 \%$ of the total variation in the dependent variable is account for by the independent variable while the remaining $98.02 \%$ is account for by other variables.

\begin{tabular}{ccrrrr}
\hline \multicolumn{5}{c}{ Table No. 2: Inflation Regressed on Interest rate } & \\
Model & Coefficient & t-Value & P-Value & R2 \\
\hline Constant & -3.41 & -0.57 & 0.57 & \multirow{2}{*}{0.0198} \\
Interest rate & 0.97 & 1.33 & 0.19 & \\
\hline
\end{tabular}


At $5 \%$ significance level, even at $10 \%$ significant level, it is found that Inflation has no significant relationship on Interest rate for Bangladesh.

Co-Integration Test: A continuation of the ADF test is employed in order to test for cointegration using the Engle and Granger method (1987). Consistent with theory nonstationary I (0) time series is employed into an OLS regression in order to estimate an error term (Residuals). An ADF test is carried out on these residuals established for OLS regression. It can also be asserted that the residuals tested for unit roots have a linear combination that makes results more reliable. If the variables are non-stationary but a linear combination between them is stationary, then the variables are co-integrated (Hatemi $-j$, 2002). This is shown in results on unit roots for ADF test which tells that the variables are no-stationary. However, a linear combination of the residuals was done and ADF test run on the time series.

\begin{tabular}{cc}
\hline \multicolumn{2}{c}{ Table No. 3: Unit Root Test for Residual } \\
Lag & $\mathrm{t}$ Value \\
\hline 1 & -1.569 \\
2 & -1.277 \\
3 & -1.326 \\
4 & -1.144 \\
5 & -1.203 \\
6 & -1.523 \\
7 & -1.867 \\
8 & -1.785 \\
9 & -1.888 \\
10 & -2.07 \\
\hline
\end{tabular}

Empirical result represents rejection of the null hypothesis at $1 \%$ and $5 \%$ significance level when MacKinnon critical value is used. All of the 10 leg's t-value does not exceed the critical value of -3.57 and 2.92 at $99 \%$ and $95 \%$ confidence level respectively. So that the null hypothesis- non-stationarity of the residual can not be rejected, that means there is no co-integration. As the variables are not co-integrated it does not show any long run equilibrium means inflation has no longer co-movement with interest rate of Bangladesh.

\section{Conclusion:}

In this study it is found that interest rate and inflation in Bangladesh behave randomly and there is no long run relationship between these two macro variables. As inflation has no significant relationship with interest rate and inflation is not depended on interest rate, government mechanism of calculating the inflation based on interest rate does not work properly in Bangladesh. When bank deposits do not provide enough return to hold the savers in the same state of purchasing power by equally adjusting the nominal interest rate with inflation, savers are looser in real terms. That can destructively influence aggregate national saving and the peoples' confidence on financial institutes; as a consequence it will effect national investments in long run. As against that, if current high inflation is adjusted with interest rate, short run investment will be adversely affected. In such situation, government should take urgent initiative to control inflation or, at least, find and remedy the forces behind the high inflation, such as, demand pull or supply push inflation, or other 
artificial factors- interruption of supply chain, many stages of intermediaries, syndicate etc. Also further investigation into this burning issue is highly recommended.

\section{References:}

Akhtaruzzaman, M. (2005) "Inflation in the Open Economy: An Application of the Error Correction Approach to the Recent Experience in Bangladesh", Working Paper Series: WP0602, Vol.1(2), Bangladesh Bank: Policy Analysis Unit.

Cagan, Phillip (1969), "The influence of interest rates on the duration of business cycles," Essays on interest rates, NBER.

Crowder, W. J. (1997) "International Evidence on The Fisher Relation”, Working Paper, Department of Economics, University of Texas at Arlington.

Darby, M. R. (1975) "The Financial and Tax Effects of Monetary Policy on Interest Rates", Economic Inquiry, Vol.13, pp. 266-276.

Duck, N. (1993), "Some International Evidence on the Quantity Theory of Money", Journal of Money, Credit and Banking, Vol.25, pp.1-12.

Engle, R. and C. Granger 1987, "Cointegration and error correction representation: estimation and testing”, Econometrica, Vol. 55, pp. 251-276.

Engsted, T. (1995), “Does the Long-Term Interest Rate Predict Future Inflation?”, Review of Economics and Statistics, Vol. 77, pp. 42-54.

Evans, L. T., Keef, S. P. and J. Okunev (1994), "Modelling Real Interest Rates", Journal of Banking and Finance, Vol.18, pp.153-165.

Evans, M. and K. Lewis (1995), "Do Expected Shifts in Inflation Affect Estimates of the Long-Run Fisher Relation?”, Journal of Finance, Vol. 50, pp. 225-253.

Fama, E. and M. R. Gibbons (1982), "Inflation, Real Returns, and Capital Investment", Journal of Monetary Economics, Vol.9, pp. 297-324.

Fama, E.F. (1975), "Short Term Interest Rates as Predictors of Inflation", American Economic Review, Vol.65, pp.269-282.

Fisher, I. (1930), The Theory of Interest, New York: Macmillan.

Fisher, M. and J. Seater (1993), "Long-Run Neutrality and Super-neutrality in an ARIMA Framework", American Economic Review, Vol.83, pp. 402-415.

Fried, J. and P. Howitt (1983), "The Effects of Inflation on Real Interest Rates", American Economic Review, Vol.73, pp. 968-979.

Hatemi- J, A (2002), "Money supply and information ally efficiency of the stock market in Korea: Evidence from an alternative Methodology", Journal of Economic Integration, Vol. 16(3), pp.427-436. 
Huizinga, J. and F. S. Mishkin (1986), "Monetary Policy Regime Shifts and the Unusual Behavior of Real Interest Rates", Carnegie-Rochester Conference Series on Public Policy, Vol.15, pp.151-200.

Kandel, S., A. Ofer and O. Sarig (1996), "Real Interest Rates and Inflation: An Exante Empirical Analysis", Journal of Finance, Vol.51, pp.205-225.

Khan, Mohsin S. and Axel Schimmelpfennig (2006), "Inflation in Pakistan: Money or Wheat?" IMF Working Paper WP/06/60, International Monetary Fund: Middle East and Central Asia Department.

Leheyda, Nina (2005), "Determinants of Inflation in Ukraine: a Cointegration Approach," Mimeo, University of Mannheim, Mannheim: Centre for Doctoral Studies in Economics and Management (CDSEM).

Liu, Olin and Olumuyiwa S. Adedeji (2000). "Determinants of Inflation in the Islamic Republic of Iran-A Macroeconomic Analysis" IMF Working Paper WP/01/198, International Monetary Fund: Middle Eastern Department.

Martin, D.D. Evans and Karen, K. Lewis (1995), "Do Expected Shifts in Inflation Affect Estimates of the Long-Run Fisher Equation?", Journal of Finance, Vol. 50, pp.225243.

Mishkin, F. S. (1992), "Is the Fisher Effect for Real? A Reexamination of the Relationship between Inflation and Interest Rates", Journal of Monetary Economics. Vol.30, pp.195-215.

Modigliani, F. and R. Cohn (1979), "Inflation, Rational Valuation, and the Market", Financial Analysts Journal, Vol. 35, pp. 24-44.

Mortaza, M. Golam (2006), "Sources of Inflation in Bangladesh: Recent Macroeconomic Experience" Working Paper Series: WP0704, Bangladesh Bank: Policy Analysis Unit, December.

Myles, Wallance S. and John Warner T. (1993), "The Fisher effect and the Term Structure of Interest Rates: Tests of Co-integration". The Review of Economics and Statistics, Vol. 2, pp. 320-324, May.

Summers, L. (1983) "The Non-adjustment of Nominal Interest Rates: A study of the Fisher Effect", in J. Tobin (Ed.), Symposium in Memory of Arthur Okun. Washington, D.C.:Brooking Institution.

Tanzi, V. (1980), "Inflationary Expectations, Economic Activity, Taxes and Interest Rates", American Economic Review, Vol. 70, pp.12-21.

Taslim, M. A. (1982), "Inflation in Bangladesh: A Reexamination of the StructuralistMonetarist Controversy" The Bangladesh Development Studies, Vol. 10(1), pp.2352.

Tobin, J. (1965), “Money and Economic Growth”, Econometrica, Vol.33, pp.671-684. 
Tobin, J. (1969), “A General Equilibrium Approach to Monetary Theory”, Journal of Money, Credit and Banking, Vol.1, pp.15-29.

Ubide, Angel (1997), "Determinants of Inflation in Mozambique," IMF Working Paper WP/97/145: International Monetary Fund.

Wallace, M. S. and J. T. Warner (1993), "The Fisher Effect and the Term Structure of Interest Rates: Tests of Cointegration", Review of Economics and Statistics, Vol. 75 , pp. 320-324.

William, J. Crowder and Dennis, L. Hoffman, (1996), "The Long-Run Relationship between Nominal Interest Rates and Inflation: The Fisher Equation Revisited". Journal of Money, Credit and Banking, Vol. 28, pp.102-118. 